\title{
A 2-es típusú cukorbetegek személyre szabott kezelése: fókuszban a korai SGLT2-gátló terápia
}

\author{
Balogh Zoltán dr., Sira Lívia dr.
}

\begin{abstract}
Ósszefoglalás
Közismert, hogy a 2-es típusú diabeteses betegek kardiovaszkuláris morbiditása és mortalitása 2-4-szerese az egészséges egyénekének, különösen a szivinfarktus, szivelégtelenség és az ischaemiás stroke gyakoribb. Napjainkban a metformin tekinthetö a 2-es típusú cukorbetegek elsö vonalbeli optimális gyógyszeres kezelésének az igazoltan kifejezett glykaemiás hatás, a kedvezö biztonságossági profil, az alacsony kezelési költség és a kardiovaszkuláris eseményekre gyakorolt jótékony hatása miatt. Az újabb antihyperglykaemiás szerek közé tartozó SGLT-2-gátlók a vesék proximalis tubulusaiban gátolják a glukóz visszaszivódását, az igy elért kifejezett glucosuria a $\mathrm{HbA}_{1 c}$ az éhomi és a postprandialis vércukorértéket egyaránt csökkenti, mindezt az endogén inzulintermeléstöl függetlenül. Nemrégen az EMPA-REG OUTCOME vizsgálat dokumentáltan magas kardiovaszkuláris rizikójú 2-es típusú cukorbetegek körében igazolta a standard antidiabetikus kezeléshez adott empagliflozinnak a kardiovaszkuláris végpontokra kifejtett elönyös hatását. A jelen közleményben az SGLT-2-gátlóknak a kardiovaszkuláris eseményekre gyakorolt hatásait tekintik át a szerzök az irodalmi adatok alapján.
\end{abstract}

Kulcsszavak: nátrium-glukóz kotranszporter-2 gátlók, kardiovaszkuláris hatások, a mindennapi klinikai gyakorlat adatai

\section{Individualized management of patients with type 2 diabetes: focus on early SGLT2-inhibitor therapy}

Summary: It is well known that patients with type 2 diabetes have 2 to 4 times increased risk of cardiovascular morbidity and mortality than healthy individuals, namely myocardial infarction, heart failure, and ischemic stroke. Nowadays, metformin remains the optimal first-line treatment choice for the management of type 2 diabetic patients, given its wellestablished glycemic efficacy and safety profile, low treatment cost, and its beneficial impact on cardiovascular endpoints. Novel glucose-lowering agents, such as SGLT-2 inhibitors reduce glucose reabsorption in the renal proximal tubules and increases renal glucose excretion via the urine leading to reduced $\mathrm{HbA}_{1}$ fasting and postprandial plasma glucose levels, independently from endogenous insulin secretion. The EMPA-REG OUTCOME study has recently shown that empagliflozin, when added to the standard of care treatment, reduced the risk of cardiovascular endpoints in patients with type 2 diabetes who were also at high cardiovascular risk. In this review we summarize the data on the impact on SGLT2 inhibitors on the risk of cardiovascular events.

Keywords: sodium-glucose transporter 2 inhibitors, cardiovascular effects, real world evidence

Rövidítések:

ACE: angiotenzin-konvertáló enzim (angiotensin-converting enzyme); ARB: angiotenzinreceptor-blokkoló (angiotensin receptor blocker); ATP: adenozin-trifoszfát (adenosine triphosphate); BMI: testtömegindex (body mass index); CANVAS: CANagliflozin cardioVascular Assessment Study; CANVAS-R: CANagliflozin cardioVascular Assessment Study-Renal; CI: konfidenciaintervallum (confidence interval); CV: kardiovaszkuláris (cardiovascular); CVD: kardio- 
vaszkuláris betegség (cardiovascular disease); CREDENCE: Evaluation of the Effects of Canagliflozin on Renal and Cardiovascular Outcomes in Participants With Diabetic Nephropathy; CTGF: Connective Tissue Growth Factor; DECLARE-TIMI 58: Dapagliflozin Effects on Cardiovascular Events; eGFR: becsült glomerulus filtrációs ráta (estimated glomerular filtration rate); ELIXA: Evaluation of Lixisenatide in Acute Coronary Syndrome trial; EMA: European Medical Agency; EMPA-REG OUTCOME: Empagliflozin, Cardiovascular Outcomes, and Mortality in Type 2 Diabetes; EXAMINE: EXamination of CArdiovascular OutcoMes with AlogliptIN vs. Standard of CarE in Patients with Type 2 Diabetes Mellitus and Acute Coronary Syndrome; FDA: Food and Drug Administration; GFR: glomerularis filtrációs ráta; GLP-1: glukagonszerü peptid-1 (glucagon-like peptid-1); GLUT-9: glukóz-transzporter-9 (glucose transporter 9); HbA $_{1 c}$ : glikált hemoglobin (glycated hemoglobin); HIF-1: hipoxia indukálta faktor-1 (hypoxia-inducible factor 1); HDL: nagy sürüségü lipoprotein (high-density lipoprotein); HR: kockázati hányados (hazard ratio); ICAM-1: intercellularis adhéziós molekula-1 (intercellular adhesion molecule 1); IL-6: interleukin-6; LDL: kis sürüségü lipoprotein (low-density lipoprotein); LEADER: Liraglutide Effect and Action in Diabetes: Evaluation of Cardiovascular Outcome Results; MR: mágneses rezonancia (magnetic resonance); NaCl: nátrium-klorid (sodium chloride); NF-KB: nuclear factor kappa B; NO: nitrogén-monoxid (nitrogen monoxide); Nox-4: NADPH-oxidáz-4 (NADPH oxidase 4); RCT: randomizált kontrollált tanulmány (randomized controlled trial); REFORM: Safety and Effectiveness of SGLT-2 Inhibitors in Patients With Heart Failure and Diabetes; ROS: reaktív oxigén species (reactive oxygen species); RWE: a mindennapi klinikai gyakorlat adatai (real world evidence); SAVOR-TIMI 53: The Saxagliptin Assessment of Vascular Outcomes Recorded in Patients with Diabetes Mellitus (SAVOR)-Thrombolysis in Myocardial Infarction (TIMI) 53 trial; SGLT-2: nátrium-glukóz kotranszporter-2 (sodium-glucose co-transporter 2); SLC2A: Solute Carrier Family 2 Member 1; SUSTAIN-6: Evaluation Cardiovascular and Other Long-term Outcomes with Semaglutide in Subjects with Type 2 Diabetes; T2DM: 2-es típusú diabetes mellitus (type 2 diabetes mellitus); TECOS: Trial Evaluating Cardiovascular Outcomes with Sitagliptin; TGF- $\beta$ : transzformáló növekedési faktor-béta (transforming growth factor beta); TNF-a: tumor-nekrózis faktor-a (tumor necrosis factor alpha); UGT: uridin-difoszfát-glukuronil-transzferáz (uridine diphosphate-glucuronosyltransferase); VCAM-1: vaszkuláris sejtadhéziós molekula (vascular cell adhesion protein-1); VLDL: nagyon alacsony sürüségü lipoprotein (very low-density lipoprotein); 8-OHdG: 8-hidroxi-2'-dezoxiguanozin (8-hydroxy-2'-deoxyguanosine)

A világszerte exponenciálisan növekvő gyakoriságú 2-es típusú diabetesben (T2DMben) a vezető halálokot változatlanul a szív-érrendszeri szövődmények, a (gyakran silent) szívinfarktus, a diabeteses cardiomyopathia következtében a pangásos szívelégtelenség, a malignus kamrai ritmuszavar okozta hirtelen halálozás és a 2-3-szor gyakoribb ischaemiás stroke jelentik. A T2DM prevalenciája 6,9-10,2\% közötti a fejlett országok, közel 7\% a fejlődő országok felnőtt lakosságának körében. ${ }^{1}$ A T2DM önmagában kb. 5-10 évvel rövidíti meg a várható élettartamot, a betegek $80 \%$-a kardiovaszkuláris betegségben hal meg. A hypertonia társulása közel kétszeresére növeli az össz-halálozást, míg a coronariabetegség kialakulásának esélyét háromszorosára emeli. ${ }^{1}$ A pangásos szívelégtelenség gyakorisága 10-20\%ra tehető a T2DM-es betegek körében, ami átlagosan 2,5-szerese a nem-diabeteses populációban észleltnek. A T2DM és a szívelégtelenség „halálos kettőse” igen rossz prognózisú, a várható átlagos élettartam mindössze 4 évre tehető, ${ }^{2}$ más adatok szerint az 5 éves túlélés esélye $<25 \%$.

A diabetes mellitus szívre gyakorolt hatásait az 1. ábrán tüntettük fel vázlatosan. ${ }^{3}$

Napjainkban a metformin tekinthető a 2-es típusú cukorbetegek első vonalbeli optimális gyógyszeres kezelésének az igazoltan kifejezett glykaemiás hatás, a kedvező biztonságossági profil, az alacsony kezelési költség és a kardiovaszkuláris eseményekre gyakorolt jótékony hatása miatt. Az újabb antihyperglykaemiás szerek közé tartozó SGLT-2-gátlók a vesék proximalis tubulusaiban gátolják a glukóz visszaszívódását, az így elért kifejezett glucosuria a $\mathrm{HbA}_{1 \mathrm{c}}$, az éhomi és a postprandialis vércukorértéket egyaránt csökkenti, mindezt az endogén inzulintermeléstől függetlenül.

Az alábbiakban az FDA és EMA által jelenleg engedélyezett három SGLT-2-gátló, az empa-, a dapa- és a canagliflozinnal kapcsolatos néhány fontosabb adatot tekintünk át (hazánkban ez utóbbi nincs forgalomban). 


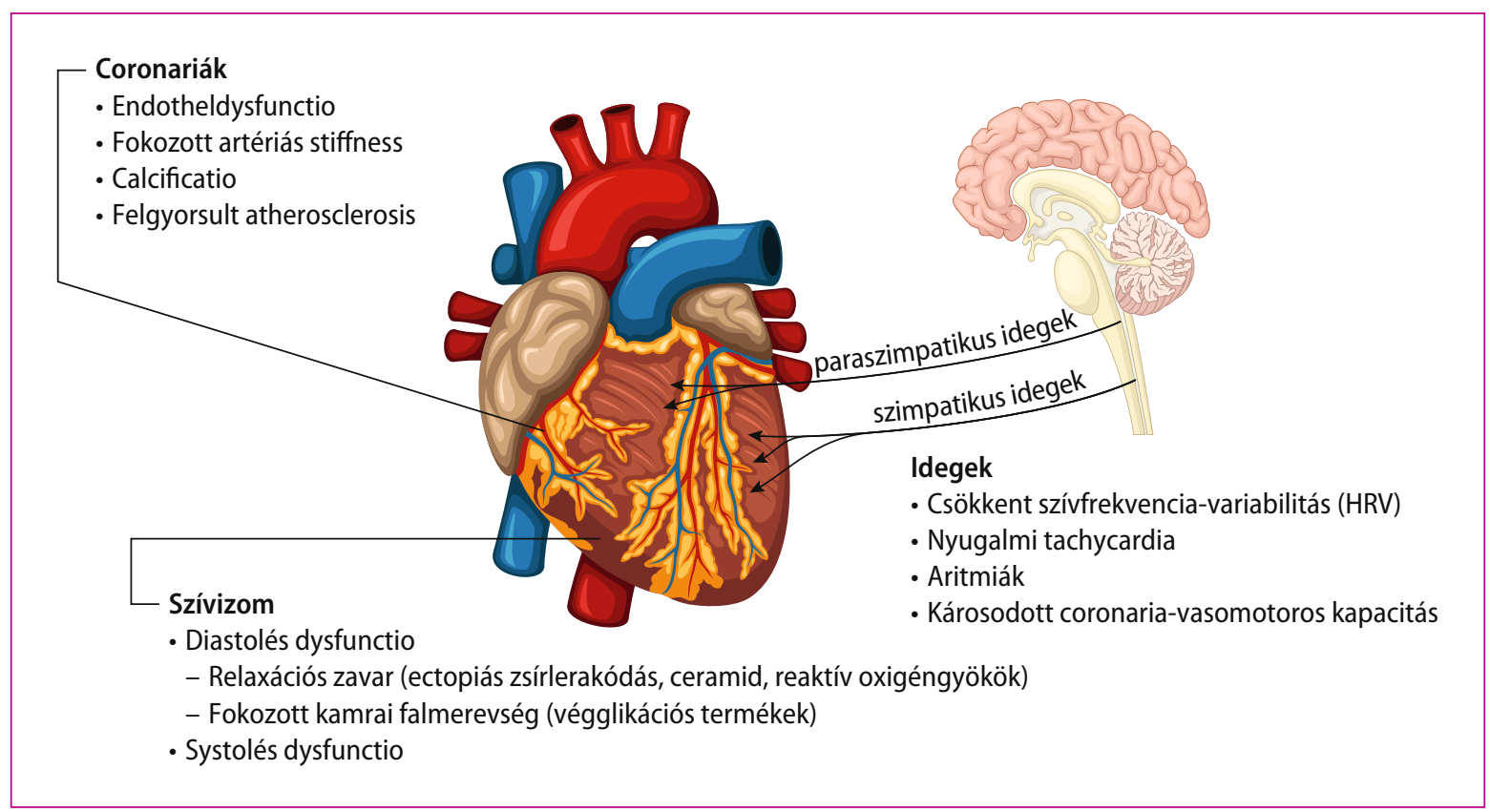

1. ábra. Diabetes mellitus komplex hatása a szívre (Retnakaran és Zinman ${ }^{3}$ alapján)

\section{Az EMPA-REG OUTCOME vizsgálat}

A 2015. szeptemberben közölt EMPA-REG OUTCOME-vizsgálatban 7020 nagy CV rizikójú (>99\%-uknak igazolt $\mathrm{CV}$ betegsége volt), $7-10 \%$ közötti kiindulási $\mathrm{HbA}_{1 c}$-értékủ és $\geq 30$ $\mathrm{ml} /$ perc/1,73 m² GFR-értékű 2-es típusú cukorbeteg 3,1 éves átlagos követési ideje alatt a standard vércukorcsökkentő kezelés kiegészítéseként adott SGLT-2-gátló empagliflozin mind napi 10, mind napi 25 mg-os adagban 14\%-kal, szignifikánsan csökkentette az elsődleges hármas összevont végpontként szereplő CV halálozás, nem fatális szívinfarktus és nem halálos stroke kialakulását (HR: $0,86,95 \%$-os CI $0,74-0,99 ; \mathrm{p}=0,04)$. Mindezt a hypoglykaemiák számának érdemi növekedése nélkül, a testsúly, a $\mathrm{HbA}_{1 c}$-érték és a vérnyomás minimális csökkenése mellett érte el. Emellett az empagliflozin mindkét napi dózisban alkalmazva a szívelégtelenség miatti kórházi kezelést 35\%kal (HR: 0,65, 95\%-os CI 0,50-0,85; p=0,0017), a kardiovaszkuláris halálozás relatív rizikóját 38\%kal (HR: 0,62, 95\%-os CI 0,49-0,77; p<0,001), az összmortalitást 32\%-kal (HR: 0,68, 95\%-os CI; $0,57-0,82 ; \mathrm{p}<0,001)$, egyaránt szignifikánsan csök- kentette. A fentiek mellett teljesült a szuperioritás kritériuma. ${ }^{4}$ Mindezt igen jó artériás érvédő „háttérkezelés" mellett érte el (az ACEI/ARB szedők aránya mindhárom csoportban 95\%, a $\beta$-blokkolót szedők aránya $65 \%$, a statint szedőké $76 \%$, az aspirint szedők aránya $83 \%$ körüli volt). Megjegyzendő, hogy a stroke (HR: 1,18, 95\%-os CI 0,89-1,56; $\mathrm{p}=0,26$ ) és a szívinfarktus (HR: $0,87,95 \%$-os CI $0,70-1,09 ; \mathrm{p}=0,23)$ kialakulása, valamint az instabil angina miatti hospitalizáció aránya nem lett ritkább az empagliflozint szedő betegek körében., ${ }^{4,5}$ Az összhalálozás jelentős javulásának hátterében elsősorban a kardiovaszkuláris halálozás és a szívelégtelenség progressziója miatti kórházi kezelések igényének nagyfokú csökkenése állhatott. A kiinduláskor ismert manifeszt szívelégtelenség aránya alacsony, 10,1\%-os volt, bár a nem-diagnosztizált szívelégtelenség (így a diasztolés működészavar) pontos aránya nem ismert (nem történt következetes szívultrahang-, szív-MR-, illetve szívelégtelenségi biomarker vizsgálat). ${ }^{6} \mathrm{~A} \mathrm{CV}$ halálozás az aktív betegcsoportban váratlanul igen korán, már 3 hónapos kezelési időtartam után egyértelműen csökkent. Ennek pontos mechanizmusa jelenleg nem ismert, elsősorban akut hemodinami- 
kai hatásokat feltételeznek, nem az érelmeszesedés lassítását. ${ }^{7}$ Az EMPA-REG OUTCOME CV kemény végpontjai alapján alkalmazása javasolt magas CV rizikójú, valamint szívelégtelen T2DMes betegek körében. ${ }^{8}$

\section{A CANVAS vizsgálat föbb adatai}

A CANVAS kardiovaszkuláris vizsgálatban 4330, átlagosan 8,2\%-os (7-10,5\% között) kiindulási $\mathrm{HbA}_{1 c}$-értékü 2-es típusú cukorbeteg 188,2 hetes (3,6 éves) átlagos követési ideje alatt az addigi vércukorcsökkentő kezelés kiegészítéseként adott SGLT-2-gátló canagliflozint napi 100 vagy napi 300 mg-os adagban adva (vs. placebo) szignifikánsan csökkent az elsődleges hármas összevont végpontként szereplő CV-halálozás, nem fatális szívinfarktus és nem halálos stroke kialakulása. A betegek beválasztásának feltétele $>30$ éves életkor igazolt coronariabetegséggel (ez a betegek 62,7\%-át tette ki), vagy $>50$ éves életkor kettő, vagy több CV rizikótényezővel. A betegek átlagos életkora 62,4 év volt kiinduláskor. A CANVAS-R vizsgálatban szintén $>30$ éves életkor igazolt coronariabetegséggel, vagy $>50$ éves életkor két, vagy több $\mathrm{CV}$ rizikótényezővel társultan volt a beválasztás kritériuma, itt elsődleges végpontként az 5812 betegen az albuminuria progressziója szerepelt. A CANVAS-R tanulmányban az albumin/kreatinin hányadost 6 havonta mérték, míg az eredeti CANVAS CV kimeneteli vizsgálatban az első 12 hét múlva, majd évente. A két vizsgálat (CANVAS program) adatait egy közleményben összesítették, így a beteglétszám 10142 fő, az átlagos követési idő 188,2 hét (3,6 év), az átlagos diabetestartam kiinduláskor 13,5 év volt. Az aktív betegcsoportban a $\mathrm{HbA}_{1 c}$-érték átlagosan $0,58 \%$-kal, a testsúly $1,6 \mathrm{~kg}$-mal, a vérnyomás 3,93/1,39 Hgmm-rel csökkent $(\mathrm{p}<0,001)$. A primer hármas összevont végpontként szereplő CV halálozás, nem fatális szívinfarktus és nem-halálos stroke kialakulása szignifikánsan csökkent ( $p<0,001$ ) (1000 beteg-évre számítva 26,9 vs. 31,5 esemény). Az összevont CANVAS vizsgálatban az elsődleges hármas összevont végpontként szereplő CV halálozás, nem fatális szívinfarktus és nem halálos stroke kialakulása 14\%-kal, szignifikáns mértékben csökkent (HR: 0,86, 95\%-os CI 0,75-0,97). Önmagukban a három végpont egyike sem vál- tozott szignifikánsan. Az albuminuria progreszsziója 37\%-kal (HR: 0,73, 95\%-os CI 0,67-0,79), a GFR-csökkenésből, a vesepótló kezelés igényéből vagy renalis eredetű halálozásból képzett öszszevont renalis végpont $40 \%$-kal csökkent (HR: 0,60, 95\%-os CI 0,47-0,77). A szívelégtelenség miatti kórházi felvételi igény 33\%-kal volt kisebb a canagliflozint szedő betegcsoport körében (HR: 0,67, 95\%-os CI 0,52-0,87). A vizsgálat megtervezése alapján a fentiek egyike sem bizonyult statisztikailag szignifikánsnak. Váratlan, és mindenképpen további magyarázatot igénylő eredmény volt a canagliflozint szedő betegcsoportban észlelt szignifikánsan $(\mathrm{p}<0,001)$ nagyobb (minor) alsó végtagi amputációs igény (1000 beteg-évre számítva 6,3 vs. 3,4 amputációs esemény). Alapvető kérdése a várható további analíziseknek a vizsgálat elindulásakor fellelhető perifériás artériás érstátusz. Nők és férfiak körében egyaránt a genitális mycosis, valamint a volumendepléció jelenségét észlelték szignifikánsan gyakrabban a canagliflozinnal kezelt betegek csoportjában. ${ }^{9}$

\section{A CVD-REAL vizsgálat}

A CVD-REAL obszervációs vizsgálatban az újonnan SGLT-2-gátló kezelést kapó 2-es típusú cukorbetegek adatait hasonlították össze az egyéb újonnan indított vércukorcsökkentő kezelésben részesülő betegek adataival. A real world evidence (tehát a mindennapi klinikai gyakorlatot tükröző) vizsgálatot hatalmas betegszámmal (közel 1,3 millió 2-es típusú cukorbetegből kiválasztott és szofisztikált statisztikai módszerekkel - 21 paraméter alapján, ún. propensity score matching módszerrel - a minél tökéletesebb összehasonlíthatóság érdekében 1:1-ben egymásnak megfeleltetett, összesen 309056 betegen) végezték. A betegadatokat hat ország (Amerikai Egyesült Államok, Norvégia, Dánia, Svédország, Németország és Egyesült Királyság) egészségügyi adatbázisaiból nyerték, a mortalitási adatok Németországban hiányoztak, a további 5 országban hozzáférhetőek voltak. Az újonnan SGLT-2-gátlót kapó cukorbetegek (összesen 154528 fő) $53 \%$-a canagliflozint, $42 \%$-a dapagliflozint, 5\%-a empagliflozint szedett. Az arányok a vizsgálatban részt vevő hat ország kezelési gyakorlatát tükrözik a 2012-2017-ig terjedő vizsgált idő- 
szakban (az Amerikai Egyesült Államokban 76\% volt a canagliflozin, a fenti európai országokban 92\% volt a dapagliflozin szedésének aránya).

A betegek átlagéletkora 57 év volt, 44\%-uk volt nő, mindössze $13 \%$-uknál volt ismert kardiovaszkuláris betegség, 67\%-uk szedett statint, 80\%-uk valamilyen vérnyomáscsökkentő szert (74\% ACEgátlót vagy ARB-t), valamint $79 \%$-uk szedett metformint. A sulfanylureaszedés aránya $38 \%$, az inzulint alkalmazók aránya $29 \%$ volt.

Mindenképpen kiemelendő, hogy a CVDREAL vizsgálatban a betegek $87 \%$-a még nem esett át kardiovaszkuláris eseményen, jól reprezentálva a mindennapi diabetológiai gyakorlatban megjelenő betegpopuláció összetételét.

A CVD-REAL vizsgálatban azt találták, hogy az SGLT-2-gátló terápia mellett a szívelégtelenség miatti hospitalizáció kockázata 39\%-kal (esélyhányados 0,$61 ; 95 \%$-os CI $0,51-0,73 ; \mathrm{p}<0,001)$, az összhalálozás rizikója pedig $51 \%$-kal volt kisebb (esélyhányados 0,49 ; 95\%-os CI 0,41-0,57; $\mathrm{p}<0,001$ ), mint az egyéb antihyperglykaemiás terápián levő betegek körében. A kockázatcsökkenés mindkét esetben szignifikánsnak bizonyult. A szívelégtelenség miatti hospitalizáció vagy összhalálozás összevont kockázata 46\%-kal csökkent (esélyhányados 0,54; 95\%-os CI 0,48-0,60; p<0,001). A fenti adatok konzisztensek voltak mind a hat részt vevő országban. ${ }^{10}$ A CVD-REAL vizsgálat alapján felmerül, hogy az SGLT-2-gátlók kardiovaszkuláris előnyei feltételezhetően az SGLT-2-gátlásra jellemző csoporthatásból következnek. Azonban a fenti adatok közvetlenül, egyedi mérlegelés nélkül nem ültethetők át a mindennapi diabetológiai gyakorlatba a fentiekben részletezett szigorú, illetve speciális betegbeválasztási kritériumok alapján.

A CVD-REAL vizsgálat adatai jól kiegészítik a korábban megismert EMPA-REG OUTCOME és a 2017. júniusban publikált CANVAS randomizált, kontrollált tanulmányok eredményeit is, egyúttal megerősítik az SGLT-2-gátlók, ezen belül a dapagliflozin kardiovaszkuláris biztonságosságát.

\section{Az SGLT-2-gátlók kardiovaszkuláris és renalis hatásainak elméletei}

Az empagliflozin okozta ozmotikus diuresis és vasodilatatio csökkenti a szív elő- és utóterhelését, következésképpen a szív munkáját, mindezt nem kíséri a szívfrekvencia növekedése. Egyes adatok szerint a glomerulo-tubularis feedback változása eredményeként 4-5\%-kal növekedett hematokritérték előnyös lehet a myocardium oxigénellátottságára. Az empagliflozin eredményezte 3-4 kg-os (2-5\%-os) testtömeg-csökkenés hátterében egyrészt az ozmotikus diuresis okozta vízvesztés, másrészt a visceralis zsírszövet mennyiségének csökkenése állhat (a testsúly csökkenése jellemzően a kezelés első 12-26 hetében történik, majd a 26. hetet követően a testsúly már általában nem változik tovább). A testsúly csökkenésének közel 70\%-áért a (dominálóan visceralis) zsír tömegének csökkenése felelős. ${ }^{11}$ Érdekes adat, hogy a BMI legalább 5\%-os csökkenése akár 25,5\%-kal csökkenti a nem alkoholos zsírmájnak az MRspektroszkópiával igazolható triglicerid-tartalmát. ${ }^{7}$ Uricosuriás hatása miatt átlagosan 10-13\%kal csökken a szérum húgysavszintje (ez a hatás a vesetubulusokban levő SLC2A9, más néven GLUT-9 transzporter rendszeren keresztül történik). ${ }^{7}$ Kedvezően alakul a lipidprofil (a szérum trigliceridszintje, valamint az LDL/HDL arány egyaránt csökken úgy, hogy a HDL-szintje 13\%-kal, az LDL-C szintje akár 10\%-kal növekedik). A renalis glukózvesztés következtében csökken a májban a VLDL termelődése, ${ }^{7}$ mérséklődik a microalbuminuria. ${ }^{12}$ Az SGLT-2-gátló hatására emelkedő plazma glukagonszint pozitív inotróp és antiaritmiás hatású. ${ }^{13} \mathrm{Az}$ ún. takarékos szubsztrát hipotézis az SGLT-2-gátlók ketogén hatásán alapul, vagyis növelik a ketontestek (a $\beta$-hidroxi-vajsav, az acetecetsav és az aceton) képződését a májban. Ennek hátterében az $\alpha$-sejtek fokozott glukagontermelése és az inzulin:glukagon hányados csökkenése áll. Míg $100 \mathrm{~g}$ acetecetsav elégetése közben 9,4 kg ATP, 100 g $\beta$-hidroxi-vajsav metabolizmusa esetén 10,5 kg ATP képződik, a glukóz lebontását kísérő 8,7 kg ATP-vel szemben. Egyes adatok szerint a ketontestek túlsúlya $28 \%$-kal javítja a szívizom mechanikai működését. Emellett a ketontestek gátolják a szabad zsírsavak felvételét és oxidációját az ektópiásan lerakódott, zsírral telített szívizomban az oxidatív stressz okozta szöveti és funkcionális károsodást. ${ }^{1}$ A fentiek értelmében a zsírsav- és glukózoxidáció helyett a több energiát (mitokondriális ATP-t) nyújtó, enyhe ketonaemia (döntően a $\beta$-hidroxi-vajsav) javíthatja a myocardi- 
um és a vesék keringését, anyagcseréjét, működését. ${ }^{1}$ Experimentális állatmodellekben igazolták az empagliflozinnak az inzulinrezisztenciát és a proinflammatorikus citokinek (TNF- $\alpha$, IL-6, MCP-1) mérséklő hatását. ${ }^{7} \mathrm{Az}$ empagliflozinnak felmerült - experimentális adatok alapján - a szívizomsejtekre kifejtett közvetlen hatásának a teóriája is, ami még bizonyításra vár. ${ }^{14}$ Az SGLT-2-gátlók jótékony kardiovaszkuláris hatásainak jelenlegi magyarázatát a 2. ábrán foglaltuk össze.

Shyangdan és munkatársai SGLT-2-gátlókkal végzett metaanalízisükben mind monoterápiában, mind (döntően metformin mellé adva) második antihyperglykaemiás szerként adva az SGLT-2gátlók 2,6-6 Hgmm-rel csökkentették a szisztolés vérnyomást, adataik szerint a napi $10 \mathrm{mg}$ dapagliflozinnak volt a legkifejezettebb a szisztolés vérnyomást mérséklő hatása. ${ }^{15}$ Ebben az NO-mediált vasodilatatio mellett a natriuretikus hatásnak, a keringő plazmavolumen csökkenésének lehet döntő szerepe. Közismert a 2-es típusú diabeteses betegek hypertoniájának sóérzékenysége, a $\mathrm{Na}^{+}$-retineáló hatás. ${ }^{7}$

\section{Az SGLT-2-gátlók nefroprotektív hatása}

A krónikus vesebetegség becsült prevalenciája amerikai T2DM-es betegek körében 43,5\%. ${ }^{5} \mathrm{Az}$ újabb adatok (így az EMPA-REG OUTCOME és a CANVAS-R) alapján az SGLT-2-gátlók jelentős nefroprotektív hatással rendelkeznek, ami a vércukorcsökkentő hatástól függetlennek tűnik, egyúttal fontos kóroki tényező a kardiovaszkuláris mortalitás csökkentésében is. Az EMPAREG OUTCOME renalis végpontokra gyakorolt hatásai közül kiemelendő, hogy a napi 10, illetve $25 \mathrm{mg}$ empagliflozin (vs. placebo) esetén 39\%-

Hemodinamikai hatások

(a natriuresis útján)

Szív-érrendszeri hatások

Plazmavolumen $\downarrow$ Vérnyomás és pulzusnyomás $\downarrow$

Artériás stiffness $\downarrow$

Szimpatikus tónus $\downarrow$

Szívelégtelenség $\downarrow$

Szívérrendszeri halálozás $\downarrow$

Ritmuszavar $\downarrow$ (?)

Mortalitás $\downarrow$

\section{Renális hatások}

TGF $\downarrow$

Hiperfiltráció $\downarrow$

intraglomerularis nyomás $\downarrow$

$\mathrm{eGFR} \rightarrow$

Proteinuria $\downarrow$ Nephropathia $\downarrow$

Renális szövődmény $\downarrow$

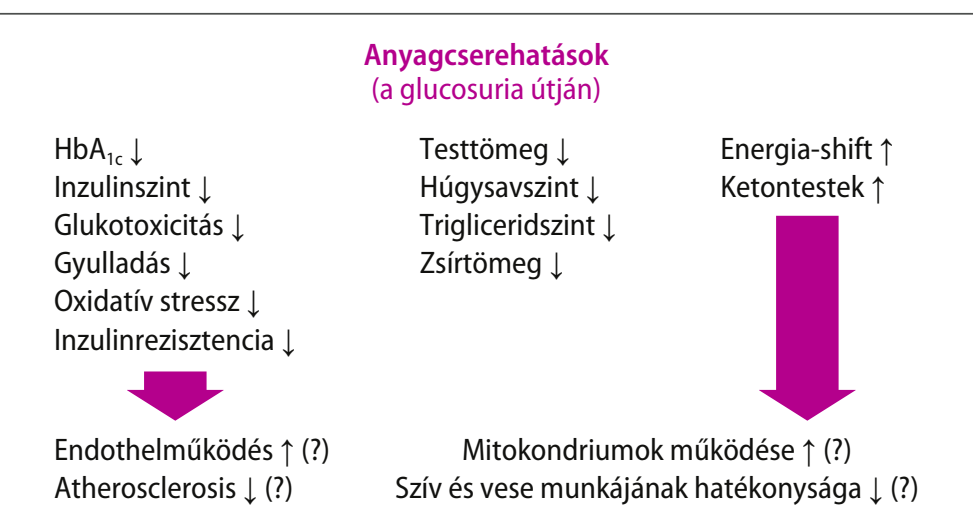

\section{2. ábra. Az SGLT-2-gátlók elönyös sziv-érrendszeri hatásainak lehetséges háttere (Tanaka és mtsai alapján)}


kal $(\mathrm{p}<0,0001)$ mérséklődött az újonnan kialakult vagy romló diabeteses nephropathia. $\mathrm{Az}$ empagliflozin csoportban a macroalbuminuriába történő progresszió, a szérum kreatininszintje megkettőződésének esélye, a vesepótló kezelés indikációja szignifikánsan csökkent, ezzel szemben az újonnan kezdődő albuminuria gyakorisága nem csökkent szignifikáns mértékben. ${ }^{16}$ A számított GFR-érték az első 4 héten átmenetileg csökkent a volumenvesztés következtében, majd stabilizálódott. ${ }^{17} \mathrm{~A}$ kedvező renalis hatások hátterében az alábbiaknak lehet szerepe, jóllehet a pontos mechanizmus még nem ismert.

Az SGLT-2-gátlók által indukált fokozott natriuresis a macula densában a NaCl-tartalmat növelve aktiválódik a tubuloglomerularis feedback, csökken az intraglomerularis nyomás (ebben a pitvari natriuretikus peptid csökkent szekréciójának is szerepe lehet) és a glomerularis hiperfiltráció. Ez utóbbiak mérséklik az albuminuriát, átmenetileg csökken, majd stabilizálódik a GFR-érték. Az artériás stiffnes és vaszkuláris rezisztencia csökken az SGLT-2-gátlás hatására, az angiotenzin II. és az aldoszteron szintje csökkenhet, míg a glukagon magas plazmaszintje javítja a vesék vérátáramlását. Az SGLT-2-gátlók feltételezett nefroprotektív hatásait a 3. ábrán foglaltuk össze.

In vitro vizsgálatokban leírták, hogy a dapagliflozin aktiválja a HIF-1 (hipoxia indukálta faktor-1), következményesen a vesékben az eritropoetin képződését, ami a vesék oxigénellátását javítva szintén hozzájárulhat a vesékre gyakorolt kedvező hatásokhoz.,17 Ígéretesnek tűnik az ACE-gátló és SGLT-2-gátló kombinációjának hatása a vesefunkciókra. ${ }^{18}$ További adatokkal szolgálhat majd a canagliflozinnak a diabeteses nephropathiára gyakorolt hatásáról a jelenleg is zajló CREDENCE vizsgálat, eredménye 2020-ban várható. ${ }^{5}$

Az SGLT-2-gátlókat monoterápiában adva a hypoglykaemia rizikója alacsony, a gyógyszer-interakciók lehetőségével érdemben nem kell számolni. Szájon át történő alkalmazásuk egyszerű és kényelmes, napi egyszeri adagolást tesz lehetővé, további előnyük, hogy dózistitrálást nem igényelnek. ${ }^{19,20}$ Többnyire nincsenek emésztőrendszeri mellékhatásaik, ritkán fejfájás, nasopharyngitis, hátfájdalom jelentkezhet, valamint enyhe genitális és alsó húgyúti infekciók jelentkeznek a placebónál gyakrabban. Nők körében a gombás fertőzések gyakoribbak. Pyelonephritis extrém ritka, a bakteriális és gombás alsó húgyúti infekciók, nőkben a vulvovaginitis, míg férfiakban a balanitis tünetei enyhék, a szokásos kezelésre többnyire jól reagálnak, ismételt kezelés ritkán szükséges. A tanulmányokban az SGLT-2-gátlók szedését emiatt igen ritkán hagyták abba a betegek. ${ }^{21}$ Ritkán (volumenhiányos, diuretikumot szedő, idős 2-es típusú, illetve off-label alkalmazásként 1-es típusú cukorbetegekben) az SGLT-2-gátlók ún. euglykaemiás ketoacidosist okozhatnak, ez kellő volumenpótlással és az előírások betartásával többnyire megelőzhető. ${ }^{22}$ Kialakulásában a magas glukagon:inzu-

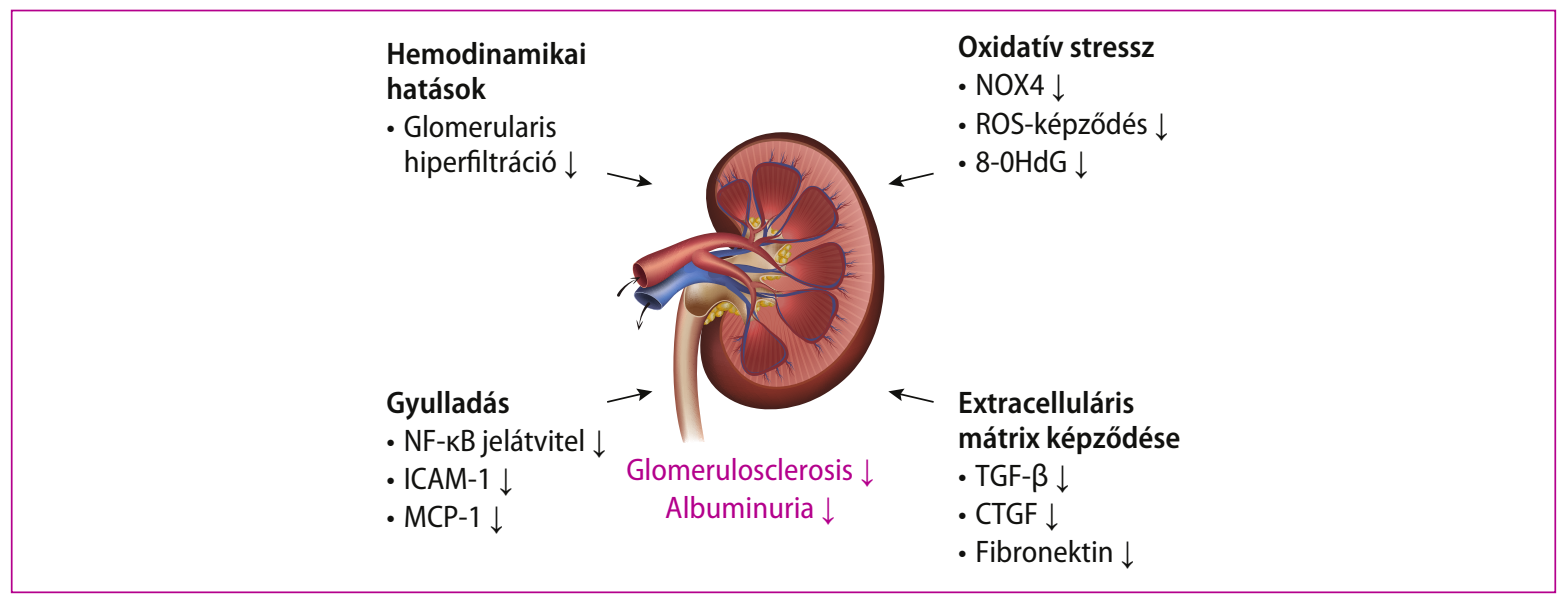

3. ábra. Az SGLT-2-gátlók feltételezett hatásai a vesékre (Kawanami és mtsai ${ }^{18}$ alapján) 
lin arány miatti fokozott ketontest-képződés és az acetecetsav fokozott renalis tubularis reabszorpciója játszhat szerepet. ${ }^{5}$ Az előzményben vagy aktuálisan húgyhólyagrák miatt kezelt betegek esetén kerülendő az SGLT-2-gátlók alkalmazása. ${ }^{11}$

\section{Összefoglalás}

A jól megtervezett és ellenőrzött, gondosan kiválogatott (többnyire magas CV rizikójú vagy igazolt coronariabetegséggel rendelkező) betegek körében elvégzett, az eseményeket (végpontokat, mellékhatásokat) jól dokumentáltan rögzítő, placebo-kontrollált, rendszeres és egységes viziteket végző randomizált, kontrollált tanulmányok, kardiovaszkuláris kemény végpontú vizsgálatok magas szintű evidenciájú adatokat szolgáltatnak. Ezek közül a SAVOR (saxagliptin), EXAMINE (alogliptin), TECOS (sitagliptin), ELIXA (lixisenatid) CV semlegességet (non-inferioritást) igazolt, míg az EMPA-REG OUTCOME (empagliflozin), a LEADER (liraglutid), SUSTAIN-6 (semaglutid) és a CANVAS (canagliflozin) egyértelmü kardiovaszkuláris előnyt mutatott (szuperioritást). ${ }^{23}$

Ezzel szemben az RWE (real-world evidence), a mindennapi klinikai gyakorlatot jobban megközelítő „valódi élet” adatait különböző (kevésbé homogén) egészségügyi regiszterek, kohorszvizsgálatok, retrospektív tanulmányok, valamint obszervációs vizsgálatok metaanalízise alapján gyüjtik össze és értékelik. Ilyenkor az utánkövetés kevéssé egységes módon, a helyi gyakorlatnak megfelelően történik, különböző aktív komparátor gyógyszerekkel szembeni az összehasonlítás, azonban kevésbé szelektált, a mindennapi gyakorlatban gondozott betegekhez jobban hasonlító betegpopulációról van szó. Ez alacsonyabb evidenciaszintet biztosít, azonban a fenti kétféle megközelítés együttesen értékelendő és ültetendő át a mindennapi beteggondozási gyakorlatunkba. ${ }^{24}$

Ez utóbbi csoportba sorolandó az Astra-Zeneca által szponzorált CVD-REAL Study is,${ }^{10}$ amely a szekunder CV prevenciósnak tekinthető EMPAREG OUTCOME vizsgálattal szemben inkább megközelíti a primer CV prevenció követelményeit.

A fentiekben leírtak alapján a metformin utáni másodvonalbeli antihyperglikemizáló készítmé- nyek közül a dokumentáltan a CV kemény végpontokat csökkentő SGLT-2-gátlók, valamint a GLP-1-receptor-agonista liraglutid preferálandó a mindennapi gyakorlatban (természetesen a mellékhatásprofil és a gyógyszerek árának figyelembevételével). ${ }^{25} \mathrm{Az}$ eddigi adatok szerint az empa-, cana- és dapagliflozin kedvező CV hatásai nagy valószínűséggel döntően csoporthatásnak tekinthetők, bár a gyógyszer-metabolizmusban (dapagliflozin: UGT1A9, canagliflozin UGT1A9, 2B4, 3A4, citokróm P2D6, empagliflozin UGT2B7, 1A3, 1A9) és az SGLT-2-gátlás szelektivitásának mértékében (SGLT2/SGLT1 gátlás aránya: dapagliflozin esetén 610, canagliflozin esetén 290, empagliflozinnál ez az arány 2680-5000 közötti) rejlő különbségek némileg árnyalhatják a fentieket. ${ }^{26}$ Szintén az SGLT-2-gátlás szelektivitásának különbségei észlelhetők az SGLT2/SGLT6 gátlás arányában: dapagliflozin és empagliflozin esetén ez az arány $>500$, canagliflozin esetén csak 90 -szeres a szelektivitás. ${ }^{27}$ A dapagliflozinnak mindössze 0,8-1,1\%-a, a canagliflozin 0-glükuronid metabolitja 33\%-ban, míg változatlan formában <1,0\%a, az empagliflozinnak 18-20\%-a ürül változatlan formában a vizelettel. A fentieknek szerepe lehet a hatások és mellékhatások különbségében is, ${ }^{28}$ így pl. a canagliflozin esetén több vizsgálatban észlelt kissé fokozott csonttörési kockázatban. A dapa-, cana- és empagliflozinnal végzett fázis 2. és 3 . vizsgálatok metaanalízisei során a kardiovaszkuláris rizikó csökkenésére gyakorolt hatások igencsak eltérő mértéke további óvatosságra int a vélt csoporthatás megítélésében. ${ }^{27,29}$ Megemlítendő, hogy a minor amputációkkal kapcsolatos felhívást a hatóság az alkalmazási előírások között a canagliflozinra tekintettel írta elő, ami az SGLT-2-gátlók indikálása és alkalmazása esetén rendszeres lábvizsgálatot és korrekt betegtájékoztatást jelent.

Továbbra is nagy várakozás előzi meg a dapagliflozinnal előzetesen ismert CV betegségben nagyrészt nem szenvedő 17276 T2DM-es beteg körében közel 6 évig végzett, jelenleg is zajló, a primer prevenciós megközelítést tükröző DECLARETIMI 58 (fázis 3B) vizsgálat 2019-ben várható adatait. ${ }^{27}$ A REFORM fázis 4 , randomizált, kettős-vak, placebokontrollált tanulmányban a napi $10 \mathrm{mg}$ dapagliflozinnak a bal kamrai funkcióra ismert szívelégtelenségben szenvedő T2DM-es betegek körében gyakorolt hatásait vizsgálják. ${ }^{30}$ 
Az eddigi CV kemény végpontú vizsgálatok és a mindennapi diabetológiai gyakorlatot jobban megközelítő CVD-REAL Study eredményei megerősítik az SGLT-2-gátlók korai, biztonságos és előnyös alkalmazását a T2DM kombinációs antihyperglykaemiás terápiájában.

\section{Köszönetnyilvánítás}

A cikk megjelenését az AstraZeneca Kft. támogatta. A közlemény a szerző saját véleményét tükrözi. Az AstraZeneca a gyógyszerei alkalmazását minden esetben az alkalmazási előírással összhangban javasolja.

A lezárás dátuma: 2017.09.27.

HU-0331

\section{rodalom}

1. Kalra S: Sodium-Glucose Cotransporter 2 (SGLT2) Inhibitors and Cardiovascular Disease: A Systematic Review. Cardiol Ther 2016; 5(2): 161-168. doi:10.1007/s40119-016-0069-z

2. Cubbon RM, Adams B, Rajwani A, Mercer BN, Patel PA, Gherardi G, et al:: Diabetes mellitus is associated with adverse prognosis in chronic heart failure of ischaemic and non-ischaemic aetiology. Diab Vasc Dis Res 2013; 10(4): 330-336. doi:10.1177/1479164112471064

3. Retnakaran R, Zinman B: Type 1 diabetes, hyperglycaemia, and the heart. Lancet 2008; 371(9626): 1790-1799. doi:10.1016/50140-6736(08)60767-9

4. Zinman B, Wanner C, Lachin JM, Fitchett D, Bluhmki E, Hantel S, et al.; EMPA-REG OUTCOME Investigators: Empagliflozin, Cardiovascular Outcomes, and Mortality in Type 2 Diabetes. N Engl J Med 2015; 373(22): 2117-2128. doi:10.1056/NEJMOa1504720

5. Trujillo JM, Nuffer WA: Impact of Sodium-Glucose Cotransporter 2 Inhibitors on Nonglycemic Outcomes in Patients with Type 2 Diabetes. Pharmacotherapy. 2017; 37(4): 481-491. doi:10.1002/phar.1903

6. Tanaka A, Node K: Emerging roles of sodium-glucose cotransporter 2 inhibitors in cardiology. J Cardiol 2017; 69(3): 501-507. doi:10.1016/j.jjc.2016.10.019

7. Lioudaki E, Androulakis ES, Whyte M, Stylianou KG, Daphnis EK, Ganotakis ES: The Effect of Sodium-Glucose Co-transporter-2 (SGLT-2) Inhibitors on Cardiometabolic Profile; Beyond the Hypoglycaemic Action. Cardiovasc Drugs Ther 2017; 31(2): 215-225. doi:10.1007/s10557-017-6724-3

8. Ponikowski P, Voors AA, Andker SD, et al: 2016 ESC Guidelines for the Diagnosis and Treatment of Acute and Chronic Heart Failure. Eur Heart J Eur Heart J 2016; 37 (27): 2129-2200. doi:10.1093/eurheartj/ehw128

9. Neal B, Perkovic V, Mahaffey KW, de Zeeuw D, Fulcher G, Erondu N, et al.; CANVAS Program Collaborative Group: Canagliflozin and Cardiovascular and Renal Events in Type 2 Diabetes. N Engl J Med 2017; 377(7): 644-657. doi:10.1056/NEJMoa1611925

10. Kosiborod M, Cavender MA, Fu AZ, Wilding JP, Khunti K, Holl RW, et al:; CVD-REAL Investigators and Study Group: Lower Risk of Heart Failure and Death in Patients Initiated on SGLT-2 Inhibitors Versus Other GlucoseLowering Drugs: The CVD-REAL Study. Circulation 2017; 136(3): 249-259. doi:10.1161/CIRCULATIONAHA. 117.029190

11. Vallianou NG, Geladari E, Kazazis CE: SGLT-2 inhibitors: Their pleiotropic properties. Diabetes Metab Syndr 2016; pii: S1871-4021(16)30226-0. doi:10.1016/j.dsx.2016.12.003

12. Balogh Z, Sira L:A2-es típusú diabetes mellitus kezelésénekúj megközelitése, fókuszban a nátrium-glukóz kotranszporter-2-gátló empagliflozin. Az elmélettöl a klinikai gyakorlatig. Diabetologia Hungarica 2015; 3: 93-98.

13. Ferrannini E, Muscelli E, Frascerra S, Baldi S, Mari A, Heise T, et al.: Metabolic response to sodium-glucose cotransporter 2 inhibition in type 2 diabetic patients. J Clin Invest 2014; 124: 499-508. doi:10.1172/JC172227

14. Luconi M, Raimondi L, Di Franco A, Mannucci E: Which is the main molecular target responsible for the cardiovascular benefits in the EMPAREG OUTCOME trial? A journey through the kidney, the heart and other interesting places. Nutr Metab Cardiovasc Dis 2016; 26(12): 1071-1078. doi:10.1016/j.numecd.2016.09.001

15. Shyangdan DS, Uthman OA, Waugh N: SGLT-2 receptor inhibitors for treating patients with type 2 diabetes mellitus: a systematic review and network metaanalysis. BMJ Open 2016; 6(2): e009 417. doi:10.1136/bmjopen-2015-009417

16. Schernthaner G, Jarvis S, Lotan C, Prázný M, Wanner C, Wascher TC: Advances in the management of cardiovascular risk for patients with type 2 diabetes: perspectives from the Academy for Cardiovascular Risk, Outcomes and Safety Studies in Type 2 Diabetes. Ther Clin Risk Manag 2017; 13: 69-79. doi:10.2147/TCRM.S121804 
17. Wanner C.: EMPA-REG OUTCOME: The Nephrologist's Point of View. Am J Med 2017; 130(6S): S63-S72. doi:10.1016/j.amjcard.2017.05.012

18. Kawanami D, Matoba K, Takeda Y, Nagai Y, Akamine T, Yokota T, et al.: SGLT2 Inhibitors as a Therapeutic Option for Diabetic Nephropathy. Int J Mol Sci 2017; 18(5): pii: E1083. doi:10.3390/ijms18051083

19. Winkler G: A dapagliflozin potenciális helye a 2-es típusú diabetes vércukorcsökkentó kezelésében. Diabetologia Hungarica 2015; 23: 25-31.

20. Jermendy Gy: Kardiovaszkuláris biztonságossági vizsgálatok SGLT-2-gátló antidiabetikumokkal 2-es típusú diabetesben. LAM 2016; 26(3): 93-99.

21. Balogh Z: Az elsö SGLT-2-gátló szerepe a 2-es típusú cukorbetegség mindennapi ellááásában. Orvostovábbképzö Szemle 2015; 22: 29-35.

22. Fralick M, Schneeweiss S, Patorno E: Risk of Diabetic Ketoacidosis after Initiation of an SGLT2 Inhibitor. N Engl J Med 2017; 376(23): 2300-2302. doi:10.1056/NEJMC1701990

23. Singh AK, Singh R: SAVOR-TIMI to SUSTAIN-6: a critical comparison of cardiovascular outcome trials of antidiabetic drugs. Expert Rev Clin Pharmacol 2017; 10(4): 429-442. doi:10.1080/17512433.2017.1287562

24. Avogaro A, Fadini GP, Sesti G, Bonora E, Del Prato S: Continued efforts to translate diabetes cardiovascular outcome trials into clinical practice. Cardiovasc Diabeto 12016; 15(1): 111. doi:10.1186/s12933-016-0431-4

25. Simó R, Hernández C: New Treatments for Type 2 Diabetes Mellitus and Cardiovascular Disease. The Revolution Has Begun. Rev Esp Cardiol (Engl Ed) 2016; 69(11): 1005-1007. doi:10.1016/j.rec.2016.07.009

26. Kashiwagi A, Maegawa H: Metabolic and hemodynamic effects of sodiumdependent glucose cotransporter 2 inhibitors on cardio-renal protection in the treatment of patients with type 2 diabetes mellitus. J Diabetes Investig 2017; 8(4): 416-427. doi:10.1111/jdi.12644
27. Javier F, Ampudia-Blasco FJ, Romera I, Ariño B, Gomis R: Following the results of the EMPA-REG OUTCOME trial with empagliflozin, is it possible to speak of a class effect? Int I Gen Med 2017; 10: 23-26. doi:10.2147/IJGM.S115566

28. Madaan T, Akhtar M, Najmi AK: Sodium glucose CoTransporter 2 (SGLT2) inhibitors: Current status and future perspective. Eur J Pharm Sci 2016; 93: 244-52. doi:10.1016/j.ejps.2016.08.025

29. Kalra S, Jain A, Ved J, Unnikrishnan AG: Sodium-glucose cotransporter 2 inhibition and health benefits: The Robin Hood effect. Indian J Endocrinol Metab 2016; 20(5): 725-729. doi:10.4103/2230-8210.183826

30. Singh JS, Fathi A, Vickneson K, Mordi I, Mohan M, Houston JG, et al.: Research into the effect of SGLT2 inhibition on left ventricular remodelling in patients with heart failure and diabetes mellitus (REFORM) trial rationale and design. Cardiovasc Diabeto 12016; 15: 97. doi:10.1186/s12933-016-0419-0

Közlésre érkezett: 2017, augusztus 17.

Közlésre elfogadva: 2017. augusztus 31.

\section{A levelezésért felelös szerző:}

\section{Dr. Balogh Zoltán}

Debreceni Egyetem Klinikai Központ, Általános Orvostudományi Kar, Belgyógyászati Intézet 4032 Debrecen, Nagyerdei krt. 98. Pf. 19. E-mail: baloghz@belklinika.com 